\title{
Stomach contents of cetaceans incidentally caught along Mangalore and Chennai coasts of India
}

\author{
Anoop A. Krishnan, K.S. Yousuf, P.L. Kumaran, N. Harish, B. Anoop, V.V. Afsal, \\ M. Rajagopalan, E. Vivekanandan, P.K. Krishnakumar*, P. Jayasankar
}

Central Marine Fisheries Research Institute, Post Box No. 1603, Ernakulam North P.O., Cochin 682 018, Kerala, India

Received 23 May 2007; accepted 7 August 2007

Available online 31 August 2007

\begin{abstract}
The stomachs of 32 individuals of seven cetacean species incidentally caught in gill net and purseseine fisheries along Mangalore and Chennai coasts (India) between 2004 and 2006 were examined. The whole stomach (fore-gut, mid-gut and hind-gut) was examined in all cases. Prey remains (666 prey items comprising six species of teleosts, one crustacean and one squid species) were found in the stomachs of eight individuals (the remaining 24 stomachs were found to be empty). All cetaceans were found to feed mostly on teleosts with wide range of trophic levels. Based on an index that included frequency of occurrence, percentage by number and by weight, the oil sardine Sardinella longiceps was the main prey in the sample. Cetaceans appear to favour both pelagic as well as demersal prey, possibly indicating surface and benthic feeding habits.
\end{abstract}

(C) 2007 Elsevier Ltd. All rights reserved.

Keywords: feeding; stomach contents; prey; cetaceans; Sardinella longiceps; Mangalore; Chennai

\section{Introduction}

Dietary studies are important to address the position of particular species within food webs (e.g., trophic status), define their ecological role and investigate the connection between organisms through predator-prey relationships. Being top predators, most cetaceans play an important role in the marine, coastal and riparian ecosystems. Analysis of stomach contents of dolphins can provide information on their diet as well as on their diving, foraging behaviour and ecology (Clarke and Kristensen, 1980).

A number of studies are available on the food habits of cetaceans in the world oceans, but there are only few studies on the feeding habits of cetaceans in the Indian seas. Karbhari et al. (1985), Natarajan and Rajaguru (1985) and Mohammed et al. (2006) have reported the food habits of the spinner dolphin

\footnotetext{
* Corresponding author. Central Marine Fisheries Research Institute, MRC of CMFRI, P.B. No. 244, Bolar, Mangalore, Karnataka 575001, India.

E-mail address: kriskupk@gmail.com (P.K. Krishnakumar).
}

(Stenella longirostris) from samples collected near Mumbai (northwest coast), Parangipettai (southeast coast) and Karnataka (southwest coast), respectively. Krishnapillai and Kasinathan (1987) have reported the food remains of the bottlenose dolphin (Tursiops aduncus) near Mandapam (southeast coast). In the present paper, stomach contents of cetaceans incidentally caught by fishing gear along Mangalore and Chennai coasts are reported.

\section{Material and methods}

\subsection{Collection and analysis of samples}

Samples of incidentally caught cetaceans that were landed by gill nets and purseseines at Mangalore, Malpe and Gangoli (southwest coast) and Chennai $\left(13^{\circ} 03^{\prime} \mathrm{N}\right.$ and $80^{\circ} 16^{\prime} \mathrm{E}$, southeast coast) during the years 2004-2006 were collected (Fig. 1). As the maximum distance between the three southwest coast centres was only $150 \mathrm{~km}$, the results of these centres were 


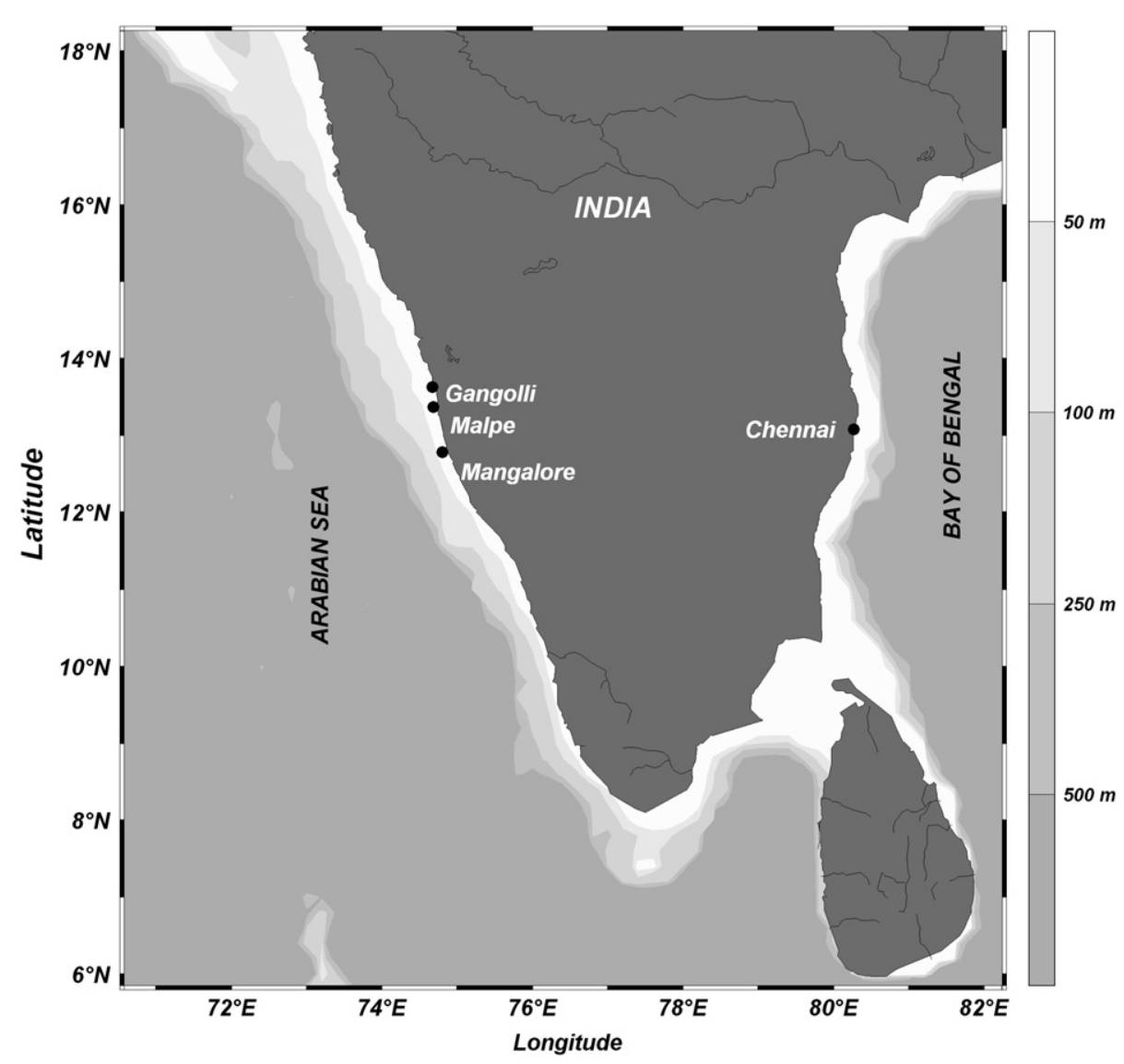

Fig. 1. Map of India showing the locations (indicated by $\bullet$ ) where the cetaceans were incidentally caught.

pooled and the collection centre is termed as Mangalore $\left(12^{\circ} 51^{\prime} \mathrm{N}\right.$ and $\left.74^{\circ} 49^{\prime} \mathrm{E}\right)$ in this paper. Stomach contents of 32 animals (belonging to seven species) were examined: 11 finless porpoise (Neophocaena phocaenoides), 13 spinner dolphin (Stenella longirostris), two bottlenose dolphin (Tursiops aduncus), two Indo-pacific humpbacked dolphins (Sousa chinensis), two Risso's dolphin (Grampus griseus), one pan-tropical spotted dolphin (Stenella attenuata) and one long beaked common dolphin (Delphinus capensis). The fishing operations in which the dolphins were caught were restricted to one day's duration and all these incidentally caught cetaceans were landed in the morning within $24 \mathrm{~h}$ of capture. The fishermen said that the cetaceans had been caught during the night. All the specimens were landed in fresh condition and their total length and sex were recorded. The location of sample collection and other details are given in Table 1.

\subsection{Examination of stomach contents}

After removal, the entire stomachs were stored in $70 \%$ ethanol until analysis. At the time of analysis, the stomach contents of each dolphin were washed and sieved through $200-\mu$ mesh. It was then processed following the procedures described by Pierce and Boyle (1991). The wet weight of contents was recorded in gram. Fish ear-bones (otoliths) were the main structures used for prey identification, based on Harkonen (1986) and Smale et al. (1995). Cephalopod mandibles (beaks) were identified following Roper et al. (1984) and Vecchione et al. (1998). All the cetaceans examined in the present study are commonly found in these areas and frequently occur in the incidental catches (CMFRI, 2007).

\subsection{Calculation of prey importance}

The following three parameters were used to investigate the occurrence and relative importance of the prey found in the stomachs: percentage by number $(\% N)$, percentage frequency of occurrence $(\% \mathrm{FO})$, percentage by weight $(\% \mathrm{~W})$ and Index of Relative Importance (IRI). Index of Relative Importance (IRI) of each prey $(i)$ is a combination of the first three parameters and was estimated following Pinkas et al. (1971) as:

$\mathrm{IRI}_{i}=\left(\% N_{i}+W_{i}\right) \% \mathrm{FO}_{i}$

\subsection{Statistical analysis}

Taxa diversity $(H)$ in the diet was estimated using the Shannon-Weiner index (Krebs, 1999) available in PRIMER (version 5 for Windows). Analysis of variance (ANOVA) was performed using SPSS (version 13.0 for Windows). 
Table 1

Details of cetaceans in which stomach contents were analysed $(\mathrm{F}=$ female; $\mathrm{M}=$ male; $\mathrm{E}=$ empty)

\begin{tabular}{|c|c|c|c|c|c|c|c|c|c|}
\hline Species & Location & Gear & $\begin{array}{l}\text { Month of } \\
\text { collection }\end{array}$ & $\begin{array}{l}\text { Length } \\
(\mathrm{cm})\end{array}$ & Sex & $\begin{array}{l}\text { Wet weight } \\
(\mathrm{g}) \text { of } \\
\text { stomach } \\
\text { content }\end{array}$ & $\begin{array}{l}\text { Prey taxa } \\
\text { (number) }\end{array}$ & $\begin{array}{l}\text { Prey } \\
\text { abundance } \\
\text { (number) }\end{array}$ & $\begin{array}{l}\text { Shannon-Wiener } \\
\text { diversity } \\
\text { index }(H)\end{array}$ \\
\hline Neophocaena phocaenoides & Mangalore & Purseseine & November-05 & 95 & $\mathrm{~F}$ & $\mathrm{E}$ & - & - & - \\
\hline Neophocaena phocaenoides & Mangalore & Purseseine & November-05 & 106 & $\mathrm{~F}$ & $\mathrm{E}$ & - & - & - \\
\hline Neophocaena phocaenoides & Mangalore & Purseseine & November-05 & 107 & $\mathrm{~F}$ & $\mathrm{E}$ & - & - & - \\
\hline Neophocaena phocaenoides & Mangalore & Purseseine & November-05 & 130.5 & $\mathrm{~F}$ & $\mathrm{E}$ & - & - & - \\
\hline Neophocaena phocaenoides & Mangalore & Purseseine & November-05 & 131 & $\mathrm{~F}$ & 190 & 1 & 15 & 0 \\
\hline Neophocaena phocaenoides & Mangalore & Purseseine & November-05 & 132 & M & $\mathrm{E}$ & - & - & - \\
\hline Neophocaena phocaenoides & Mangalore & Purseseine & November-05 & 138 & M & $\mathrm{E}$ & - & - & - \\
\hline Neophocaena phocaenoides & Mangalore & Purseseine & November-05 & 138.5 & M & $\mathrm{E}$ & - & - & - \\
\hline Neophocaena phocaenoides & Mangalore & Purseseine & November-05 & 142.5 & $\mathrm{~F}$ & 128 & 3 & 12 & 0.722 \\
\hline Neophocaena phocaenoides & Mangalore & Purseseine & November-05 & 145 & M & $\mathrm{E}$ & - & - & - \\
\hline Neophocaena phocaenoides & Mangalore & Purseseine & November-05 & 146 & M & $\mathrm{E}$ & - & - & - \\
\hline Sousa chinensis & Mangalore & Gill net & December-05 & 171 & $\mathrm{~F}$ & $\mathrm{E}$ & - & - & - \\
\hline Sousa chinensis & Mangalore & Gill net & November-05 & 273.5 & M & 620 & 4 & 50 & 0.898 \\
\hline Delphinus capensis & Mangalore & Gill net & February-06 & 190 & $\mathrm{~F}$ & 105 & 4 & 9 & 0.849 \\
\hline Stenella longirostris & Mangalore & Gill net & September-04 & 139.5 & M & 200 & 1 & 11 & 0 \\
\hline Stenella longirostris & Chennai & Gill net & October-04 & 84 & M & $\mathrm{E}$ & - & & - \\
\hline Stenella longirostris & Chennai & Gill net & October-04 & 85 & M & $\mathrm{E}$ & - & & - \\
\hline Stenella longirostris & Chennai & Gill net & October-04 & 86 & $\mathrm{~F}$ & 20 & 1 & 10 & 0 \\
\hline Stenella longirostris & Chennai & Gill net & October-04 & 89 & M & 25 & - & & - \\
\hline Stenella longirostris & Chennai & Gill net & October-04 & 94 & M & $\mathrm{E}$ & & & - \\
\hline Stenella longirostris & Chennai & Gill net & October-04 & 95.5 & M & $\mathrm{E}$ & - & & - \\
\hline Stenella longirostris & Chennai & Gill net & October-04 & 154 & $\mathrm{~F}$ & $\mathrm{E}$ & - & & - \\
\hline Stenella longirostris & Chennai & Gill net & October-04 & 158 & M & $\mathrm{E}$ & - & & - \\
\hline Stenella longirostris & Chennai & Gill net & October-04 & 162 & M & $\mathrm{E}$ & - & & - \\
\hline Stenella longirostris & Chennai & Gill net & October-04 & 164.5 & M & $\mathrm{E}$ & - & & - \\
\hline Stenella longirostris & Chennai & Gill net & October-04 & 165 & $\mathrm{~F}$ & 170 & 2 & 557 & 0.024 \\
\hline Stenella longirostris & Chennai & Gill net & October-04 & 170 & M & $\mathrm{E}$ & - & & - \\
\hline Stenella attenuata & Chennai & Gill net & October-04 & 93 & M & $\mathrm{E}$ & - & & - \\
\hline Tursiops aduncus & Chennai & Gill net & October-04 & 140 & M & $\mathrm{E}$ & - & & - \\
\hline Tursiops aduncus & Chennai & Gill net & October-04 & 153 & M & $\mathrm{E}$ & - & & - \\
\hline Grampus griseus & Chennai & Gill net & September-04 & 174 & M & $\mathrm{E}$ & - & & - \\
\hline Grampus griseus & Chennai & Gill net & October-04 & 241 & $\mathrm{~F}$ & $\mathrm{E}$ & - & & - \\
\hline
\end{tabular}

\section{Results}

Of the 32 individuals examined, 24 had empty stomachs (Table 1). The empty stomachs of the individuals were in shrunken condition, suggesting that the dolphins had not ingested food for quite some time before capture. In one Stenella longirostris (length: $84 \mathrm{~cm}$ ) and one Stenella attenuata (length: $93 \mathrm{~cm}$ ) collected off Chennai, milk was found in semi-digested condition in the mouth. In the stomachs with food: of eight individuals, seven stomachs were partially full, and only one stomach was full. The full stomach belonged to a Sousa chinensis of $273.5 \mathrm{~cm}$ total length (the food weighed $620 \mathrm{~g}$ ). In the eight stomachs with stomach-remains a total of 666 prey items were recorded (Table 2). Of this, 559 items $(83.9 \%)$ were crustaceans, $104(15.6 \%)$ were teleosts and three $(0.5 \%)$ were squids. The prey remains identified belonged to six species of teleosts (six families), one crustacean and one squid (Table 2). The main teleost families identified were Clupeidae (Indian oil sardine), Nemipteridae (threadfin breams), Muraenesocidae (pike conger), Synodontidae (lizardfish) and Lactariidae (false trevallies). In addition, several unidentified (partially digested) fishes were present. The shrimp Solenocera crassicornis formed the main constituent numerically forming $83.6 \%$ of the prey consumed. However, this species was found in only one dolphin (S. longirostris) collected at Chennai. Squid beaks were retrieved from Neophocaena phocaenoides.

Teleosts were the main prey by weight $(87.4 \%)$, followed by crustaceans $(12.0 \%)$. Teleosts contributed $86 \%$ to the total IRI. The IRI of the oil sardine, Sardinella longiceps, was highest $(12,425)$ (Table 2), followed by the conger eel, Muraenesox cinereus, and the threadfin bream, Nemipterus japonicus. Sousa chinensis showed the highest Shannon-Wiener diversity index ( $H=0.898)$, followed by Delphinus capensis $(H=0.849)$. One of the Stenella longirostris showed the lowest diversity index $(H=0.024)$ (Table 1). ANOVA indicated that there was no significant $(P>0.05)$ difference in taxa diversity $(H)$ between the species.

\section{Discussion}

The present study, as in the majority of quantitative dietary studies of marine mammals, pertains to small number of samples and a small fraction of species range, and hence cannot be considered to represent the complete food habits of the cetaceans analysed. A few conclusions may, however, be drawn from this study. 
Table 2

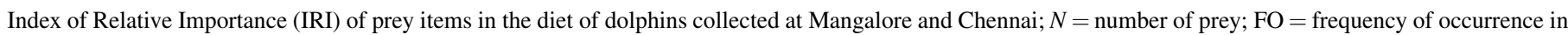
the stomach; $W=$ weight of prey $(\mathrm{g})$

\begin{tabular}{|c|c|c|c|c|c|c|c|c|c|c|}
\hline Species & Prey species & Family & $N$ & $\% N$ & $\mathrm{FO}$ & $\% \mathrm{FO}$ & $W$ & $\% W$ & IRI & $\%$ IRI \\
\hline \multicolumn{11}{|l|}{ Location: Mangalore } \\
\hline \multirow[t]{3}{*}{ Neophocaena phocaenoides } & Sardinella longiceps & Clupeidae & 24 & 88.9 & 2 & 66.7 & 310 & 97.5 & 12,425 & 96.5 \\
\hline & Loligo sp. & Loliginidae & 3 & 11.1 & 1 & 33.3 & 8 & 2.5 & 454 & 3.5 \\
\hline & Total & & 27 & & 3 & & 318 & 100 & 12,879 & 100 \\
\hline \multirow[t]{2}{*}{ Stenella longirostris } & Nemipterus sp. & Nemipteridae & 11 & 100 & 1 & 100 & 200 & 100 & 20,000 & 100 \\
\hline & Total & & 11 & & 1 & & 200 & & 20,000 & \\
\hline \multirow[t]{4}{*}{ Sousa chinensis } & Nemipterus sp. & Nemipteridae & 30 & 60 & 1 & 33.3 & 300 & 48.4 & 3613 & 54.2 \\
\hline & Saurida sp. & Synodontidae & 15 & 30 & 1 & 33.3 & 300 & 48.4 & 2613 & 39.2 \\
\hline & Lactarius lactarius & Lactariidae & 5 & 10 & 1 & 33.3 & 20 & 3.23 & 441 & 6.6 \\
\hline & Total & & 50 & 100 & 3 & 100 & 620 & 100 & 6667 & 100 \\
\hline \multirow[t]{4}{*}{ Dephinus capensis } & Muraenesox cinereus & Muraenesocidae & 6 & 66.7 & 1 & 33.3 & 100 & 95.2 & 5397 & 81.0 \\
\hline & Prawns & & 2 & 22.2 & 1 & 33.3 & 0.5 & 0.5 & 757 & 11.3 \\
\hline & Unidentified fish & & 1 & 11.11 & 1 & 33.3 & 4.5 & 4.3 & 513 & 7.7 \\
\hline & Total & & 9 & 100 & 3 & 100 & 105 & 100 & 6667 & 100 \\
\hline \multicolumn{11}{|l|}{ Location: Chennai } \\
\hline \multirow[t]{5}{*}{ Stenella longirostris } & Solenocera crassicornis & Solenoceridae & 557 & 97.9 & 1 & 33.3 & 172.3 & 88.5 & 6214 & 93.2 \\
\hline & Stolephorus sp. & Engraulidae & 2 & 0.4 & 1 & 33.3 & 2.3 & 1.2 & 51 & 0.8 \\
\hline & Unidentified fishes & & 10 & 1.8 & 1 & 33.3 & 20 & 10.3 & 401 & 6.0 \\
\hline & Total & & 569 & & 3 & & 194.6 & & 6667 & 100 \\
\hline & Grand total & & 666 & & 13 & & 1438 & & 52,879 & \\
\hline
\end{tabular}

The stomachs of $75 \%$ of cetaceans studied were empty, which is similar to the stomach emptiness reported for several finfishes (Vivekanandan, 2001). Selzer et al. (1986) have postulated that unusually high percentages of empty stomachs are expected to occur in incidentally caught cetaceans. However, studies suggesting the opposite can also be found (Berrow and Rogan, 1996), and no strong evidence seems to point either way (Silva, 1999). In the present study, eight individuals were below $1 \mathrm{~m}$ lengths and six of them had empty stomachs. They were juveniles and were perhaps in the weaning stage. This was evident from the presence of milk in the mouth of the two of the six juvenile specimens. Most of the individuals in the present study were caught between dusk and dawn. In one purseseine haul lasting from 1800 hours to 2000 hours off Gangoli, 14 Neophocaena phocaenoides were caught. In addition to the porpoises the catch consisted of about $500 \mathrm{~kg}$ of the oil sardine Sardinella longiceps and the squid Loligo sp. This observation indicates that prey were abundantly available for the porpoises. The stomachs of 11 dead porpoises were removed and it was observed that nine stomachs were empty. So it appears that the presence of prey did not induce the majority of the individuals to feed. Perhaps the cetaceans have specific time and schedule for feeding.

The four species of cetaceans, for which data on stomach contents are available, feed mostly on teleosts, which have a wide range of trophic levels from 2.0 (oil sardine) to $>4.0$ (lizardfish and eel) (Vivekanandan et al., 2005). Pauly et al. (1998) reported the trophic level of the four species of cetaceans as 4.0-4.3. The stomach of one Stenella longirostris (off Chennai) consisted of the shrimp Solenocera crassicornis (a demersal species inhabiting at around $50 \mathrm{~m}$ depth) and the whitebait Stolephorus sp (a pelagic species), indicating the surface and bottom feeding. The drift gill nets and purseseines, in which the cetaceans were incidentally caught, operated in the surface waters. There is thus evidence for surface as well as bottom feeding habits, and their capture at the surface indicates that these cetaceans dive frequently to depths for the purpose of feeding. Most of the prey inhabit the depth range of 20-80 $\mathrm{m}$ and contribute to the commercial fishery indicating the likely cetaceans/fisheries interaction. The squid beaks found in the stomach of the finless porpoise confirmed the feeding of these species in coastal waters as the squid family Loliginidae is found in shallow waters in depth of 30-170 m (Roper et al., 1984; Vecchione et al., 1998). The results of the present study generally agree with previous findings of Karbhari et al. (1985) and Mohammed et al. (2006) where they found fish and squid as the main prey of dolphins. The present study and that of Natarajan and Rajaguru (1985) indicate that the cetaceans along the southeast coast feed mainly on shrimps.

\section{Acknowledgments}

We are thankful to the Director, CMFRI, Cochin for his encouragement and for the facilities. We thank the two anonymous reviewers for suggestion and our colleagues in CMFRI for their constant help and encouragement in collecting and dissecting the specimens. It is a pleasure to express our gratitude to all the fishermen who provided information on cetaceans and their incidental catches. This study was funded by Ministry of Earth Sciences, Government of India.

\section{References}

Berrow, S.D., Rogan, E., 1996. Stomach contents of harbour porpoises and dolphins in Irish waters. European Research on Cetaceans 9, 179-181. 
Clarke, M.R., Kristensen, R.R., 1980. Cephalopod beak from the stomach of two northern bottle nosed whales (Hyperoodon ampullatus). Journal of the Marine Biological Association of the United Kingdom 60, 151-156.

CMFRI, 2007. Studies on Marine Mammals of Indian EEZ and the Contiguous Seas. Final Report submitted to Ministry of Earth Sciences, New Delhi.

Harkonen, T.J., 1986. Guide to the Otoliths of the Bony Fishes of the Northeast Atlantic. Danbui ApS, Hellerup, 256 pp.

Karbhari, J.P., Aravindakshan, M., Wagmare, K.B., Gandhi, R., 1985. Note on the food of the spinner dolphin Stenella longirostris Gray, caught off Maharashtra coast. Journal of Marine Biological Association of India 27, 193-195.

Krebs, C.J., 1999. Ecological Methodology. Addison Wesley Longman, Inc., Menlo Park, CA, 620 pp.

Krishnapillai, S., Kasinathan, C., 1987. Some observations on dolphins in Mandapam area with a note on their food. Marine Fisheries Information Service $71,13-16$.

Mohammed, K.S., Zacharia, P.U., Muthiah, C., Abdurahiman, K.P., Nayak, T.H., 2006. A Trophic Model of the Arabian Sea Ecosystem off Karnataka and Simulation of Fishery Yields for its Multigear Marine Fisheries. Central Marine Fisheries Research Institute publication, pp. 1-83. Available from: www.ecopath.org/publications.

Natarajan, R., Rajaguru, A., 1985. Small cetaceans. Marine Mammal Science 1, 89.

Pauly, D., Trites, A.W., Capuli, E., Christensen, V., 1998. Diet composition and trophic levels of marine mammals. ICES Journal of Marine Science 55, 467-481.

Pierce, G.J., Boyle, P.R., 1991. A review of methods for diet analysis in piscivorous marine mammals. Oceanography and Marine Biology an Annual Review 29, 409-486.
Pinkas, L., Oliphant, M.S., Iverson, I.L.K., 1971. Food habits of albacore, bluefish tuna and bonito in California waters. Fisheries Bulletin 152, 1-105. Department of Fish \& Game, California.

Roper, C.F.E., Sweeney, M.J., Nauen, C.E., 1984. FAO Species Catalogue. Vol. 3. Cephalopods of the World. An Annotated and Illustrated Catalogue of Species of Interest to Fisheries. In: FAO Fish. Synopsis, vol. 125. pp. $1-262$.

Selzer, L.A., Early, G., Fiorelli, P.M., Prescott, R., 1986. Stranded animals as indicators of prey utilization by harbour seals, Phoca vitulina concolor in Southern New England. Fishery Bulletin 84, 217-220. National Oceanic and Atmospheric Administration, Washington, D.C.

Silva, M.A., 1999. Diet of common dolphins, Delphinus delphis, off the Portuguese continental coast. Journal of the Marine Biological Association of the United Kingdom 79, 531-540.

Smale, M.J., Watson, G., Hecht, T., 1995. Otolith Atlas of Southern African Marine Fishes. Ichthyological Monographs 1, 235.

Vecchione, M., Brakoniecki, T.F., Natsukari, Y., Halon, R.T., 1998. A provisional generic classification of the family Loliginidae. In: Voss, N.A., Vecchione, Toll, R.B., Sweeney, M.J. (Eds.), Systematics and Biogeography of Cephalopods, vol. I. Smithsonian Institution Press, Washington, D.C., pp. $215-222$.

Vivekanandan, E., 2001. Predatory diversity of two demersal finfish species in the trawling grounds off Veraval. Indian Journal of Fisheries 48, 133-143.

Vivekanandan, E., Srinath, M., Kuriakose, S., 2005. Fishing down marine food web along the Indian coast. Fisheries Research 72, 241-252. 